\title{
Digital Competence and Computational Thinking of Student Teachers
}

\author{
https://doi.org/10.3991/ijet.v15i02.11588 \\ Francesc M. Esteve-Mon $\left.{ }^{\bowtie}\right)$, M. Angeles Llopis, Jordi Adell-Segura \\ Universitat Jaume I, Castelló, Spain \\ festeve@uji.es
}

\begin{abstract}
Digital competence is one of the most demanded skills, and includes, among other aspects, the use of technological, informational, multimedia or communication skills and knowledge. In recent years, different institutions have included computational thinking among the different areas that make up this digital competence. However, there are few publications that deepen the relationship between computational thinking and digital competence. The present study analyzes the level of digital competence and computational thinking of 248 Spanish university students, exploring the relationships between both abilities and the existing differences. According to the results, the majority of the students perceive themselves with a medium to a high level of digital competence, highlighting the multimedia and communicative dimensions, as opposed to the more technological aspects. On the other hand, there is a correlation between computational thinking and digital competence, especially with the communicative and technological areas. Likewise, the results indicate that women obtain lower results in their computational thinking and are perceived to be digitally less competent than men, especially in regard to the technological dimension. These results provide relevant information in terms of research and open the door to the development of training actions in student teachers to overcome the still-existing gender gaps.
\end{abstract}

Keywords-Digital competence, computational thinking, teacher training, evaluation

\section{Introduction}

The enormous proliferation of Information and Communication Technologies (ICT) has meant that individuals have to face situations that require the use of new technical, cognitive and social skills every day. Skills that have led to the so-called 'digital competence' [1]. During the last decades, many authors have tried to define this digital competence (DC), putting the emphasis on the different aspects technological, informational, media, etc.- that make it up [2], [3]. The European Commission, which has recently redefined this competence as the safe, critical and responsible use of digital technologies in learning, work or participation in society [4], has included computational thinking among the different areas that make it up, for the 
first time. In recent years, computational thinking (CT) has become one of the emerging educational trends internationally [5].

But how are future teachers prepared for this necessary digital competence and computational thinking? On one hand, different research points out that although these university students use technology in a generalized way, its use is mainly focused on communicative and social [6], [7], and informational activities [8], having an adequate and complete level of digital competence [9], [10]. On the other hand, research on the computational thinking of student teachers is still limited [11], and there are few publications that explore the relationship between computational thinking and digital competence in depth [12].

Despite the fact that the development of these skills has been introduced in the training of student teachers [13], there is still a gender gap even today [14]. In fact, gender differences in terms of computational thinking and digital competence have been highlighted by multiple authors, with disparate and sometimes contradictory results [15], [16], [17].

The present study presents an analysis of the digital competence of university students of education, as well as the level of their computational thinking, exploring the relationships between both abilities and the existing differences.

\subsection{The digital competence}

[18] Was one of the first authors to address the concept of digital literacy, linking it with the set of skills related to access, evaluation, and management of information, multimedia and through a network. It is about literacy linked to the use of tools for accessing and managing information and digital resources, building new knowledge and communicating [19]. A literacy that goes beyond simple technical skills for the use of devices, and that involves a set of technical-procedural, cognitive and socioemotional skills, necessary to live, learn and work in a digital society [20], [21].

However, despite the fact that the concept of digital literacy seems to be the most widely used at the international level, the term digital competence is often used synonymously, especially in the European context [22]. According to [23], digital competence requires the involvement of four dimensions or literacies:

- Information literacy (IL), the recognition of the need for information, its location, evaluation, organization and transformation

- Technological literacy (TL), hardware and software management and data processing in different formats

- Multimedia literacy (ML), analysis, understanding, and the creation of multimedia messages

- Communicative literacy (CL), the dissemination of information and participation in a safe, ethical and civic way as a digital citizen.

Similarly, the Joint Research Center (JRC) defines digital competence in the following five areas [24]: 
- Literacy related to information and data, that is, searching, evaluating and managing information and digital content

- Communication and collaboration through digital technologies, sharing content, participating in online citizenship following the rules of participation in the network called Netiquette and managing the digital identity

- Creation of digital content, re-elaborating and integrating it and programming, keeping in mind the licenses and the author's rights

- Security in reference to the protection of devices, personal data, health and the environment

- Solution of technical problems, identification of needs and technological answers, creative use of technology and identification of technical problems

\subsection{The computational thinking}

According to [25], computational thinking involves solving problems, designing systems and understanding human behavior, based on the fundamental concepts of computer science, and includes a wide variety of mental tools that reflect the breadth of the field of computing. The International Society for Technology in Education (ISTE) and the Computer Science Teachers Association (CSTA) attempted to 'operationalize' the definition as a problem-solving process that includes (but is not limited to) the following characteristics:

- Formulate problems in a way that allows us to use a computer and other tools to help solve them

- Organize and analyze data logically

- Represent data through abstractions such as models and simulations

- Automate solutions through Algorithmic thinking (a series of ordered steps)

- Identify, analyze and implement possible solutions in order to achieve the most effective and effective combination of steps and resources

- Generalize and transfer this problem solving process to a wide variety of problems [26]

Several authors have elaborated lists of elements or essential components of computational thinking [27], or processes of the solution of problems [28]. [29] have proposed the following list: abstraction, generalization, decomposition, algorithms (sequencing and control flow) and debugging. In addition, they structured them into three age levels for Primary (6-8, 9-10 and 11-12 years). [5] also included automation. Other authors and institutions have proposed variations and nuances in the definition and description of its fundamental elements [30], [31].

In recent years, there has been an increase in the number of experiences in the introduction of computational thinking in basic and secondary education [32], as well as in higher education [13]. On the other hand, some evaluation test of computational thinking in education has also appeared [33], whose items include different concepts (e.g. basic sequences, loops, conditional, or simple functions), response alternatives 
(arrows and blocks), and cognitive tasks required (sequences, terminations and debugging).

\subsection{Research questions}

This article aims to answer the following research questions:

- Does digital competence correlate with computational thinking?

- Are there significant gender differences in digital competence or computational thinking?

\section{$2 \quad$ Method}

\subsection{Participants}

The present study was conducted during the 2017-18 and 2018-19 courses. Participants of this study were 248 Spanish university students of Teacher Training Program (78\% females and 22\% males), 196 were between 20 and 22 years, and 52 were 23 or more, with a total average age of 21 years $(\mathrm{SD}=2.83)$.

\subsection{Instruments}

INCOTIC: The Inventory of Competencies in Information and Communication Technologies is a questionnaire of self-perception of the digital competence of university students. In addition to a series of items on biodata and on the availability of ICT resources, and digital competence section (20 items distributed from the 4 literacies - informational, technological, multimedia and communicative, with a 5-points Likert-type format. The design and validation process of this tool can be found in [34].

TPC: The Computational Thinking Test is composed of 32 questions independent of previous knowledge of a programming language. Each item addresses one or more of the 7 following computational concepts: Basic directions, 'repeat', 'repeat until', 'if', 'if/else', 'while', and simple functions. According to the authors, these concepts are aligned with CSTA standards for science education [35].The scale was recalculated to a range of $1-5$, and in order to explain the results, we used the following labels: $1-1.79=$ poor; $1.8-2.59=$ fair; $2.6-3.39=$ average; $3.4-4.19=$ good; $4.2-5=$ excellent.

\subsection{Procedure and analysis design}

Participants were recruited through an advert in their teacher education classes and participation was voluntary. The student's answers to both questionnaires were stored in Google Drive databases, downloaded as an Excel .xls files, and subsequently analyzed with the SPSS software (version 21). For the analysis, we calculated descriptive statistics, Pearson's R correlation, and the non-parametric Mann-Whitney U test. 


\section{Results}

This section presents the main results obtained after the application of different instruments and analysis techniques.

Next, the descriptive results of the digital competence and its different literacies are presented, as well as computational thinking. As we can see in Figure 1, the highest scores corresponded to multimedia (3.64) and communicative (3.56) literacies, while the lowest were technological literacy (3.23) and computational thinking (3.2).

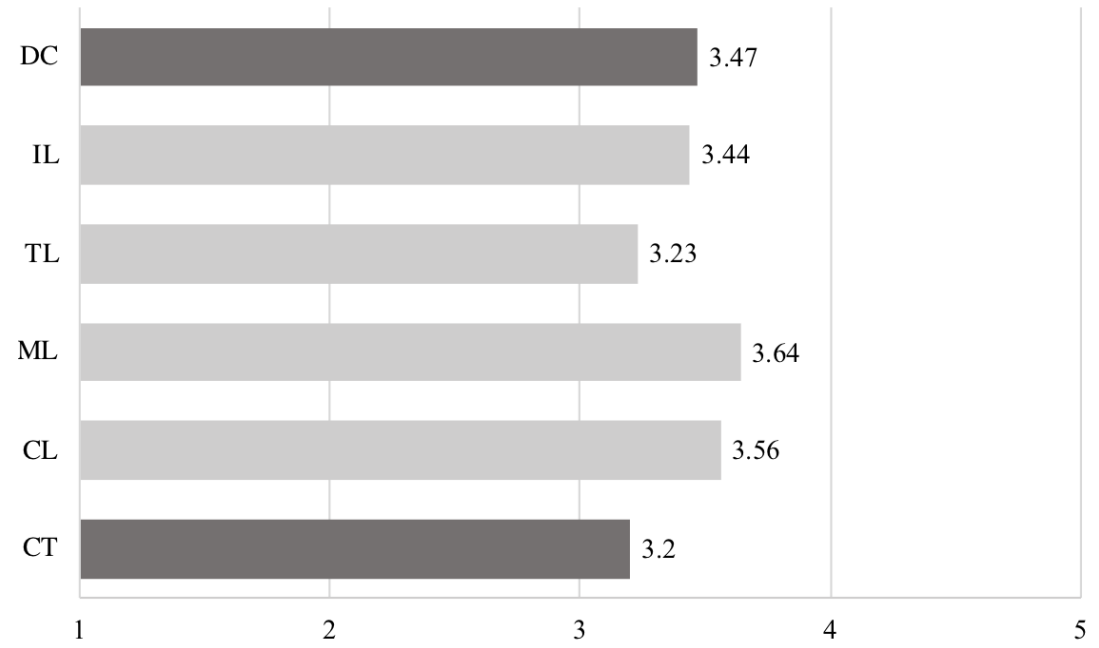

Fig. 1. Mean scores of digital competence and its dimensions and computational thinking

In Table 1, we can analyze this in more detail, based on the standard deviation (SD) and the distribution of the scores. Technological literacy and computational thinking are the two with a higher SD, as well as a higher percentage of average responses with Poor and Fair values.

Table 1. Descriptive results of digital competence and computational thinking

\begin{tabular}{|l|c|c|c|c|c|c|}
\hline \multirow{2}{*}{$*$} & \multirow{2}{*}{ M (SD) } & \multicolumn{6}{|c|}{ Percent (\%) } \\
\cline { 3 - 7 } & & Poor & Fair & Average & Good & Excellent \\
\hline Digital competence & $3.47(.60)$ & 1 & 7 & 36 & 46 & 10 \\
\hline Informational lit. & $3.44(.72)$ & 1 & 7 & 34 & 39 & 19 \\
\hline Technological lit. & $3.23(.86)$ & 2 & 22 & 28 & 33 & 15 \\
\hline Multimedia lit. & $3.64(.62)$ & 1 & 4 & 23 & 50 & 22 \\
\hline Communicative lit. & $3.56(.74)$ & 1 & 7 & 27 & 38 & 27 \\
\hline Computational thinking & $3.20(.77)$ & 5 & 15 & 40 & 29 & 12 \\
\hline
\end{tabular}

If we analyze the general value of digital competence, we can see that most students $(56 \%)$ perceive themselves as Good or Excellent in digital competence, $36 \%$ as Average and only $8 \%$ as Poor or Fair. However, if we revise the computational think- 
ing, $41 \%$ of the students have a Good or Excellent level, a $40 \%$ Average and a $20 \%$ Poor or Fair.

Table 2 shows the results of the Pearson correlation between digital competence and its different literacies, and computational thinking.

Table 2. Pearson correlation between digital competence and computational thinking

\begin{tabular}{|l|c|c|c|c|c|}
\hline & DC & IL & TL & ML & CL \\
\hline Computational thinking & $0.198^{* *}$ & 0.088 & $0.235^{* *}$ & 0.093 & $0.199^{* *}$ \\
\hline
\end{tabular}

As can be seen, there is a statistically significant positive correlation ( $p<0.01)$, and low intensity, between computational thinking and digital competence, technological literacy and communicative literacy (Figure 2, 3 and 4). On the contrary, there is no statistically significant correlation between computational thinking and information literacy or multimedia literacy.

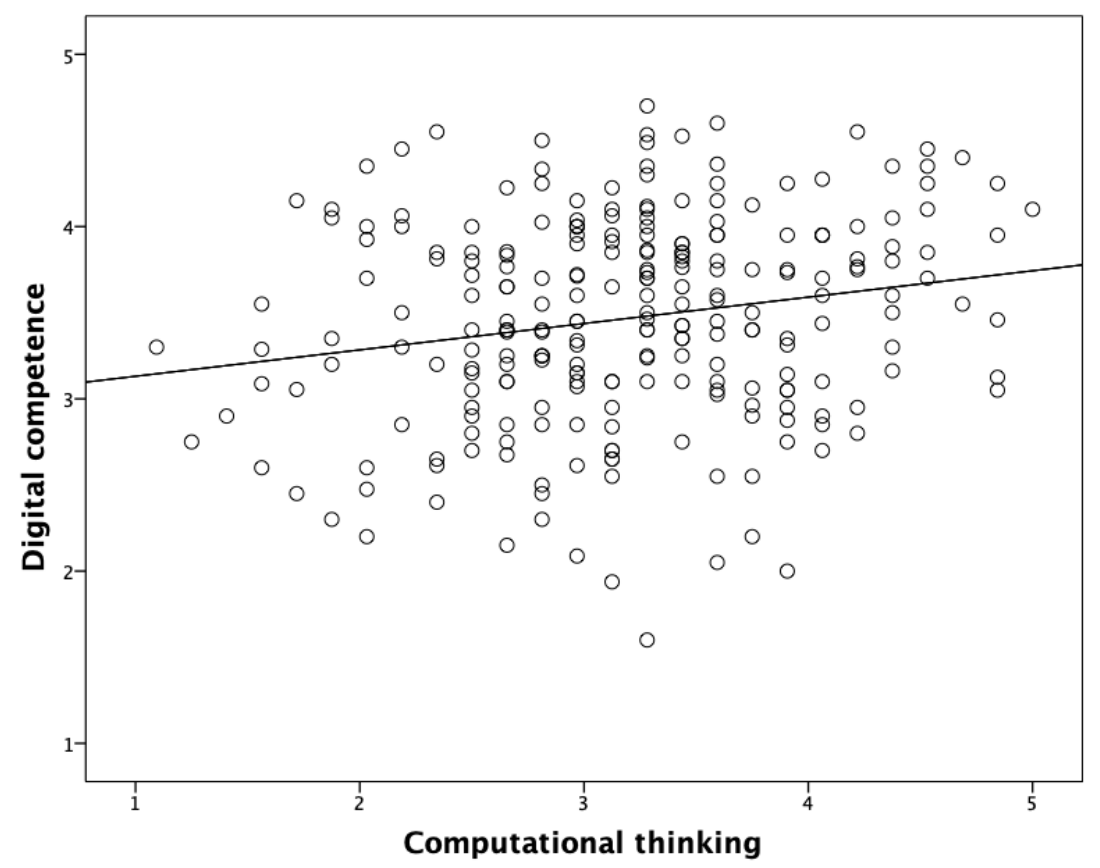

Fig. 2. Scatter plot between digital competence and computational thinking 


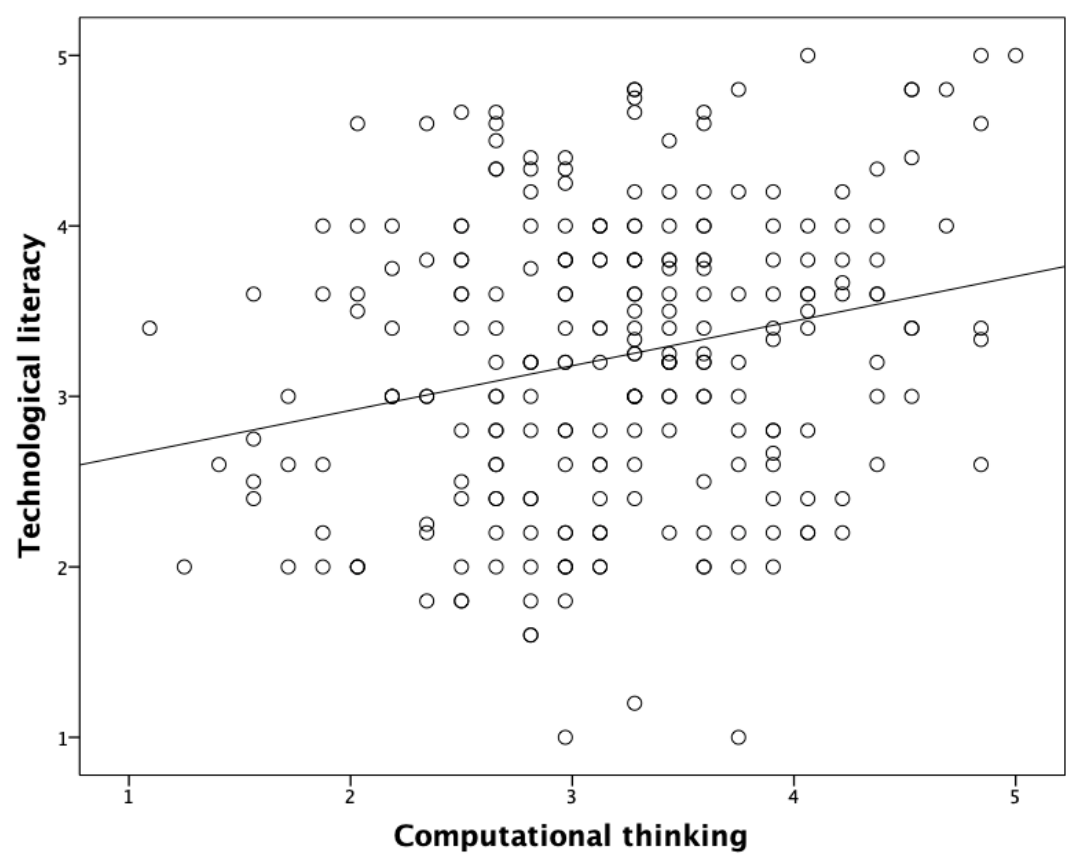

Fig. 3. Scatter plot between technological literacy and computational thinking

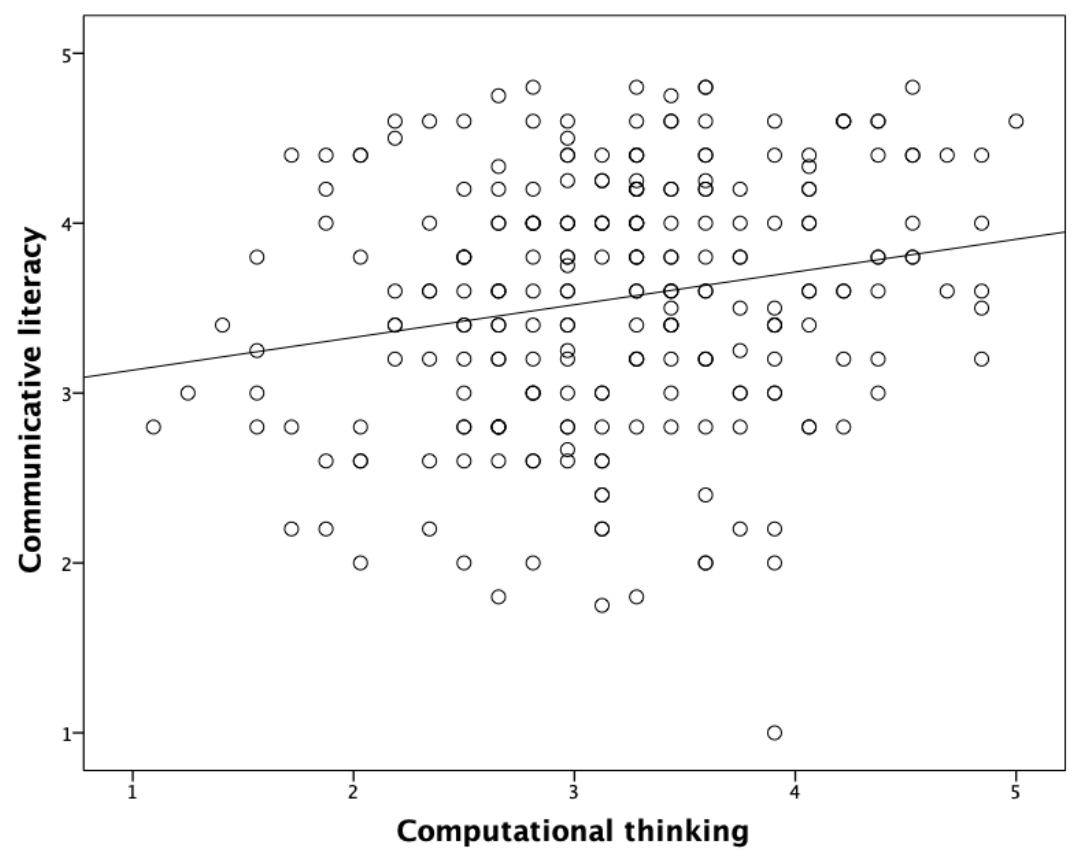

Fig. 4. Scatter plot between communicative literacy and computational thinking 
In Table 3, we can observe the average scores obtained in computational thinking and digital competence, as well as in their respective literacies.

Table 3. Statistics with regards to gender

\begin{tabular}{|l|c|c|c|c|c|c|}
\hline & DC & IL & TL & ML & CL & CT \\
\hline Males & 3.60 & 3.42 & 3.48 & 3.78 & 3.70 & 3.65 \\
\hline Females & 3.43 & 3.45 & 3.16 & 3.60 & 3.52 & 3.07 \\
\hline
\end{tabular}

At first glance, men obtain a score higher than that of women in all elements, except for information literacy, in which the average score of women is slightly higher than that of men. After analyzing the differences, from the non-parametric MannWhitney U test, we can observe that the differences between men and women are statistically significant in technological literacy and computational thinking (Table 4). In the first case, the effect size is small $(<20)$, while in the second case it is medium $(<50)$.

Table 4. Mann- Whitney U test with regards to gender

\begin{tabular}{|l|c|c|c|c|c|}
\hline & $\begin{array}{c}\text { Mann- } \\
\text { Whitney U }\end{array}$ & Wilcoxon W & Z & $\begin{array}{c}\text { Asymp. Sig. } \\
\text { (2 tailed) }\end{array}$ & $\begin{array}{c}\text { r (effect } \\
\text { size) }\end{array}$ \\
\hline Digital competence & 4418 & 23333 & -1.759 & 0.079 & 0.11 \\
\hline Informational lit. & 5030 & 6515 & -0.447 & 0.655 & 0.03 \\
\hline Technological lit. & 4165.5 & 23080.5 & -2.304 & 0.021 & 0.15 \\
\hline Multimedia lit. & 4364.5 & 23279.5 & -1.881 & 0.060 & 0.12 \\
\hline Communicative lit. & 4373 & 23288 & -1.860 & 0.063 & 0.12 \\
\hline Computational thinking & 2867.5 & 21782.5 & -5.095 & 0.000 & 0.32 \\
\hline
\end{tabular}

\section{Discussion}

Starting from the importance of digital competence and computational thinking as key skills for citizenship and the lack of studies that deepen their analysis, this study focuses on such exploration in university students of education.

As we see in the descriptive results, most of the students perceive themselves with a medium-high digital competence, emphasizing especially the multimedia and communicative dimensions, with the more technical aspects being inferior. These results are in line with those of [6] and [36], who highlight that, for future teachers, social and media are perceived as easy skills, while they find the strong difficulties in the management of hardware and software, and in the automation of technological solutions [37]. On the other hand, [7] also state that the technological knowledge of student teachers is, in many cases, even inferior to their pedagogical knowledge and content. On the other hand, and although with slightly lower values, university students of education obtained a medium-high score in their computational thinking. According to [38], there is a significant lack of knowledge among student teachers about what is computational thinking, and there is still an important improvement path [39]. 
Regarding the research questions, the first question posed the possible correlation between digital competence and computational thinking. According to the results obtained, there is a correlation between computational thinking and digital competence. If we explore the dimensions that make up this competence, we also see that there is a correlation between computational thinking and, on the one hand, communicative literacy, and on the other, and with greater intensity, technological literacy. According to data gathered, we could understand that students with a greater perception of their digital competence, especially in regards to the technological use of hardware and software, obtain a higher score in their computational thinking, and on the contrary, a student with a lower score in computational thinking tends to have a worse perception of his or her own digital and technological competence.

Regarding the second research question, significant differences were obtained regarding gender. Thus, women tend to perceive themselves as digitally less competent than men, being a significant difference in regard to the technological dimension. On the other hand, women obtain a significantly lower score than men with respect to their computational thinking. These data are in tune with similar researches, especially related to technical skills [15], [40], but contrast with those presented by [14], who did not find gender differences in skills related to programming and computer learning.

\section{Conclusion}

This study has allowed us to delve into the analysis of a key competence, such as digital in university students of education. A generation of student teachers who, in addition to acquiring a necessary basic literacy to access information, manage and evaluate it critically, or to create and share multimedia digital content, should be able to teach such skills to their future students.

From a few years to now, one of those necessary skills that integrate digital competence is computational thinking. Teachers and student teachers must also have an adequate capacity to formulate problems, logically analyze information, abstract and automate solutions, and implement them and transfer them to other realities. In addition, they should be able to develop these skills in their future students, creating teaching activities and using useful resources, such as educational robotics [41].

One of the challenges that we face is to overcome the gender gap that still exists today related to technology, and to the STEM areas. Therefore, it is essential that teachers have good competence in these areas, and that they are capable of developing and awakening scientific vocations among the smallest, something that as we have seen, is related to their own self-perception.

Without a doubt, we are aware that the present investigation contains a series of limitations. On one hand, the research has a good sample of university students of education of a Spanish university, so it would be interesting to expand to other universities and contexts, which allows for additional verification of the validity and transfer of the results. On the other hand, and although computational thinking has been evaluated based on a performance test, digital competence is analyzed based on 
the self-perception of the participants, which could be revised for future research. In addition, a future line of study could involve the development of some intervention with students that allows adequate compensation for gender differences.

Undoubtedly, digital competence and the different elements that make it up are fundamental aspects of training in the 21 st century. The growing trend of emerging technologies, such as robotics, the Internet of Things, or artificial intelligence, among many other aspects, pose new challenges that as training entities we cannot ignore.

\section{Acknowledgement}

This research was funded by an educational innovation grant from the Unitat de Suport Educatiu (USE) of the Universitat Jaume I, EDUBOT (Ref: 3437/17).

\section{$7 \quad$ References}

[1] Lankshear, C. \& Knobel, M. (2008). Digital literacies: Concepts, policies and practices. New York: Peter Lang.

[2] Khlaisang, J., \& Koraneekij, P. (2019). Open Online Assessment Management System Platform and Instrument to Enhance the Information, Media, and ICT Literacy Skills of 21st Century Learners. International Journal of Emerging Technologies in Learning (IJET), 14(07), 111-127. https://doi.org/10.3991/ijet.v14i07.9953

[3] Covello, S. (2010). A review of digital literacy assessment instruments. New York: Syracuse University.

[4] European Commission. (2018). Council recommendation of 22 May 2018 on key competences for lifelong learning (2018/C 189/01).

[5] Bocconi, S., Chioccariello, A., Dettori, G., Ferrari, A. \& Engelhardt, K. (2016). Developing computational thinking in compulsory education implications for policy and practice. Seville: Joint Research Centre. http://doi.org/10.2791/792158

[6] Lei, J. (2009). Digital natives as preservice teachers: What technology preparation is needed? Journal of Computing in Teacher Education, 25(3), 87-97.

[7] Valtonen, T., Pontinen, S., Kukkonen, J., Patrick, D., Väisänen, P. \& Hacklin, S. (2011). Confronting the technological pedagogical knowledge of Finnish Net Generation student teachers. Technology, Pedagogy and Education, 20(1), 3-18. https://doi.org/10.1080/14759 39X.2010.534867

[8] Ozdamar-keskin, N., Ozata, F. Z., Banar, K. \& Royle, K. (2015). Examining digital literacy competences and learning habits of open and distance learners. Contemporary Educational Technology, 6(1), 74-90.

[9] Liesa Orús, M., Vázquez-Toledo, S. \& Lloret-Gazo, J. (2016). Identificación de las fortalezas y debilidades de la competencia digital en el uso de aplicaciones de internet del alumno de primer curso del Grado de Magisterio. Revista Complutense de Educacion, 27(2) 845-862. https://doi.org/10.5209/rev_RCED.2016.v27.n2.48409

[10] Mesároš Vúsi, F. \& Mesároš, P. (2010). Digital competencies in process of creating the knowledge company in construction sector. In: Proceedings of the 27th International Symposium on Automation and Robotics in Construction IAARC, Bratislava, Slovakia, pp. 544-550. https://doi.org/10.22260/ISARC2010/0058 
[11] Yadav, A., Zhou, N., Mayfield, C., Hambrusch, S. \& Korb, J. T. (2011). Introducing computational thinking in education courses. In: Proceedings of the 42nd ACM Technical Symposium on Computer Science Education, Dallas, TX. https://doi.org/10.1145/1953163. 1953297

[12] Adell, J., Llopis, M. A., Esteve, F., \& Valdeolivas, M. G. (2019). El debate sobre el pensamiento computacional en educación. RIED, Revista Iberoamericana de Educación a Distancia, 22(1). https://doi.org/10.5944/ried.22.1.22303

[13] Yadav, A., Stephenson, C. \& Hong, H. (2017). Computational thinking for teacher education. Communications of the ACM, 60(4), 55-62. https://doi.org/10.1145/2994591

[14] Espino, E. E. \& González, C. S. (2015). Estudio sobre diferencias de género en las competencias y las estrategias educativas para el desarrollo del pensamiento computacional. Revista de Educación a Distancia (RED), 46. https://doi.org/10.6018/red/46/12

[15] Gui, M. \& Argentin, G. (2011). Digital skills of internet natives: Different forms of digital literacy in a random sample of northern Italian high school students. New Media \& Society, 13(6), 963-980. https://doi.org/10.1177/1461444810389751

[16] Hargittai, E. \& Shafer, S. (2006). Differences in Actual and Perceived Online Skills: The Role of Gender. Social Science Quarterly, 87(2), 432-448. https://doi.org/10.1111/j.15406237.2006.00389.x

[17] Ritzhaupt, A. D., Liu, F., Dawson, K. \& Barron, A. E. (2013). Differences in Student Information and Communication Technology Literacy Based on Socio-Economic Status, Ethnicity, and Gender. Journal of Research on Technology in Education, 45(4), 291-307. https://doi.org/10.1080/15391523.2013.10782607

[18] Gilster, P. (1997). Digital literacy, New York: Wiley Computer.

[19] Martin, A. (2005). DigEuLit--a european framework for digital literacy: A progress report. Journal of eLiteracy, 2(2), 130-136.

[20] Eshet-Alkalai, Y. (2012). Thinking in the digital era: A revised model for digital literacy. Issues in Informing Science and Information Technology, 9, 257-276. https://doi.org/10.28 $\underline{945 / 1621}$

[21] Nawaz, A. \& Kundi, G. M. (2010). Digital literacy: An analysis of the contemporary paradigms. Journal of Science and Technology Education Research, 1(2), 19-29.

[22] Ferrari, A. (2012). Digital competence in practice: An analysis of frameworks. Seville: European Commission, Joint Research Centre (JRC).

[23] Larraz, V. (2013). La competència digital a la Universitat (Dissertation Thesis). Universitat d'Andorra, Sant Julià de Lòria, Andorra.

[24] Vuorikari, R., Punie, Y., Carretero, S. \& Van den Brande, L. (2016). DigComp 2.0: The Digital Competence Framework for Citizens. Update Phase 1: The conceptual reference model. Luxembourg Publication Office of the European Union.

[25] Wing, J. M. (2006). Computational thinking. Communications of the ACM, 49(3), 33-35. https://doi.org/10.1145/1118178.1118215

[26] ISTE. (2011). Operational Definition of Computational Thinking for K-12 Education, International Society for Technology in Education.

[27] Barr, V. \& Stephenson, C. (2011). Bringing computational thinking to K-12: What is involved and what is the role of the computer science education community? ACM Inroads, 2, (1), 48-54. https://doi.org/10.1145/1929887.1929905

[28] Grover, S. \& Pea, R. (2013). Computational Thinking in K-12: A Review of the State of the Field. Educational Researcher, 42(1), 38-43. https://doi.org/10.3102/0013189X124630 51 
[29] Angeli, C., Voogt, J., Fluck, A., Webb, M., Cox, M., Malyn-Smith, J. \& Zagani, J. (2016). A K-6 Computational Thinking Curriculum Framework: Implication for Teacher Knowledge. Educational Technology \& Society, 19(3), 47-57.

[30] Aho, A. V. (2012). Computation and Computational Thinking. The Computer Journal, 55, (7), 832-835. https://doi.org/10.1093/comjnl/bxs074

[31] Wing, J. M. (2011). Computational thinking. In: IEEE Symposium on Visual Languages and Human-Centric Computing, Pittsburgh, PA. https://doi.org/10.1109/VLHCC.2011.60 $\underline{70404}$

[32] Bustillo, J. \& Garaizar, P. (2014). Scratching the surface of digital literacy... but we need to go deeper. In: IEEE Frontiers in Education Conference, Madrid, Spain, pp. 1-4. https:// doi.org/10.1109/FIE.2014.7044224

[33] Román-González, M., Moreno-León, J., \& Robles, G. (2017). Complementary Tools for Computational Thinking Assessment. In: International Conference on Computational Thinking Education, Hong Kong.

[34] González, J., Esteve, F., Larraz, V., Espuny, C. \& Gisbert, M. (2018). INCOTIC 2.0. Una nueva herramienta para la autoevaluación de la competencia digital del alumnado universitario. Profesorado, Revista de Currículum y Formación del Profesorado, 22(4), 133152. https://doi.org/10.30827/profesorado.v22i4.8401

[35] Román-González, M., Pérez-González, J.-C., Moreno-León, J. \& Robles, G. (2018). Can computational talent be detected? Predictive validity of the Computational Thinking Test. International Journal of Child-Computer Interaction, 18, 47-58. https://doi.org/10.1016/j.i jcci.2018.06.004

[36] Sadaf, A., Newby, T. J. \& Ertmer, P. A. (2012). Exploring pre-service teachers' beliefs about using Web 2.0 technologies in K-12 classroom. Computers \& Education, 59(3), 937945. https://doi.org/10.1016/j.compedu.2012.04.001

[37] Prendes, M. P., Castañeda, L. \& Gutiérrez, I. (2010). Competencias para el uso de TIC de los futuros maestros. Comunicar, Revista Científica de Educomunicación, 18(35), 175182. http://doi.org/10.3916/C35-2010-03-11

[38] Bower, M. \& Falkner, K. E. (2015). Computational Thinking, the Notional Machine, Preservice Teachers, and Research Opportunities. In: Proceedings of the $17^{\text {th }}$ Australasian Computing Education Conference, Sydney, Australia.

[39] García-Peñalvo, F. J. \& Mendes, A. J. (2018). Exploring the computational thinking effects in pre-university education. Computers in Human Behavior, 80, 407-411. https://doi. org/10.1016/j.chb.2017.12.005

[40] Kaarakainen, M.-T., Kivinen, A. \& Kaarakainen, S.-S. (2017). Differences between the genders in ICT skills for Finnish upper comprehensive school students: Does gender matter? Seminar.Net, 13(2).

[41] Kanbul, S., \& Uzunboylu, H. (2017). Importance of Coding Education and Robotic Applications For Achieving 21st-Century Skills in North Cyprus. International Journal of Emerging Technologies in Learning (IJET), 12(01), 130-140. https://doi.org/10.3991/ijet.v $\underline{12 \mathrm{i} 01.6097}$

\section{Authors}

Francesc M. Esteve-Mon is Commissioner for digital matters of the rector' office and Assistant Professor in the Department of Pedagogy at Universitat Jaume I, Spain. He teaches in Initial Teacher Education program. He participates in the Teaching, 
Learning and Technology Research Group (GREAT), and develops his research on digital competence, teacher education, and design-based research.

M. Ángeles Llopis is a Lecturer in the Department of Pedagogy at Universitat Jaume I, Spain. She teaches in Initial Teacher Education program and coordinates the internships of student teachers. Ph.D. in Education, she develops her research work in GREAT Research Group center on reflective and computational thinking, and digital competence.

Jordi Adell Segura is the Head of the Center for Education and New Technologies (CENT), and Associate Professor in the Department of Pedagogy at Universitat Jaume I, Spain. He is the coordinator of the Teaching, Learning and Technology Research Group (GREAT), and his teaching and research activity focus on educational technology.

Article submitted 2019-08-29. Resubmitted 2019-10-05. Final acceptance 2019-10-05. Final version published as submitted by the authors. 